\title{
Da'ish, Stasis and Bare Life in Iraq
}

\section{Introduction}

In tracing the roots and the emergence of al-Dawla al-Islamiya fi al-Iraq wa-Sham

(Da'ish) across Iraq in the summer of 2014, a story of marginalisation, demographic changes and geopolitical agendas is revealed. When combined, these stories explain why some individuals and communities declared $b a y^{\prime} a$ (allegiance or following) to Da'ish, which allowed the group to gain control over large parts of Syria and Iraq and declare a caliphate. Post2003, the Iraqi state underwent an existential transformation with the toppling of Saddam Hussein and the Ba'athist regime, along with experiencing a brutal manifestation of an al-Al Qa'ida franchise. Da'ish emerged out of the chaos and uncertainty of such post-invasion conditions, where sectarian violence had become prevalent, imbuing the country with a sense of inherent difference with violent characteristics. To understand the roots of Da'ish, this chapter considers political and demographic changes before the emergence of Da'ish focusing on the tensions between the oikos -(the family) = and polis (- the city). ${ }^{1}$ In the case of Iraq this tension is between the sectarian identities and state politics, which has often led to the exclusion of masses of people both during the Ba'ath period and post-2003 invasion. Thus leading to the emergence of bare life - a life form that ${ }_{L}$ according to the Italian philosopher Giorgio Agamben, is stripped from political agency, but that is still accountable to the state. ${ }^{2}$ Supplementing this is the concept of stasis - civil war - which helps to identify the tensions inherent within the state. Using Agamben's concepts allows us to map out and better understand the contributing factors that lead to the rise of Da'ish, including political exclusion, sectarianism ${ }_{L}$ and geopolitical agendas.

This chapter begins by looking at narratives of exclusion during the early years of the Iraqi state before turning to the events of the 2003 invasion. It then considers demographic changes in Iraq $_{L}$ and how they are related to the sectarian divisions and the geopolitical agendasin Iraq. From this, a pattern emerges where Sunni communities were excluded from post-2003 Iraqi politics. It is in these conditions that Da'ish were able to gain supporters, from the de-politicisation of the political. Using concepts from Agamben's canon of work on sovereignty, we are better placed to understand such processes.

\section{Bare Life and Stasis}

In an essay entitled, Stasis: Civil War as a Political Paradigm, the Italian philosopher Giergie Agamben bemoans the lack of theoretical development around the concept of civil war in the academy. ${ }^{3}$ Across 13 points - a style used by Agamben in other works - the essay explores the concept of civil war within Western political philosophy, suggesting that the necessity of civil war and of exclusion creates a secret solidarity, which he argues is central to his concept of bare life, a fundamental tension that is inherent within his political project.
Formatted: Font: +Headings (Calibri), 12 pt, Italic

Formatted: Font: Not Italic 
Stasis, in Greek, is the concept of civil war which, for Agamben, remains a fundamental aspect of contemporary political life. Agamben's work suggests that stasis emerges through tensions between the oikos -- the de-politicised family - and polis - the political city_--and from this, the oikos is seen to be "simultaneously the origin of division and stasis and the paradigm of reconciliation". ${ }^{4}$ In this way, stasis

Formatted: Font: Not Italic

constitutes a zone of indifference between the unpolitical space of the family and the political space of the city. In transgressing this threshold, the oikos is politicized; conversely, the polis is "economized," that is, it is reduced to an oikos. This means that in the system of Greek politics civil war functions as a threshold of politicization and depoliticization, through which the house is exceeded in the city and the city is depoliticized in the family. ${ }^{5}$

Understanding this relationship helps to reveal how stasis emerges, as a hidden paradigm within the relationship between oikos and polis. For Agamben, the oikos is the source of stasis, excluded from the city "through the production of a false fraternity" ${ }^{6}$ yet it does not solely reside within the oikos, as stasis is perhaps best seen in the collapse of the distinction between internal and external, friend and enemy, and oikos and polis; it is the politicisation of the oikos and the de-politicisation of the polis. The collapse of such distinctions reveals the complexity of contemporary political life amidst competing claims to power and legitimacy and efforts to regulate life.

As Agamben later argues, "the civil war assimilates and makes undecidable brother and enemy, inside and outside, household and city. In the stasis, the killing of what is most intimate is indistinguishable from the killing of what is most foreign". ${ }^{7}$ Opposition between oikos and polis is simultaneously an implication of the former in the latter amidst the conflict of "blood kinship", which results in stasis. Those familiar with the work of Ibn Khaldun may note parallels with his work on asab $\neq i y a h$, the development of kinship amongst communities as part of broader efforts to ensure survival. Such strategies are a regular feature of Middle Eastern state building efforts and the Iraqi case is no different, offering a devastating example of the tensions between oikos and polis amidst the evisceration of the sovereign project, of asabiyah. The emergence of civil war -- -broadly driven by sectarian violence albeit couched in context specific contingency - - -reveals the evisceration and collapse of of blood kinship around sectarian, tribal and ethnic identities that are (not) the bearers of political meaning. We can then see that the oikos is contained within the polis through an exclusion and the politicisation of the oikos; meaning that stasis - a threshold of indifference between oikos and polis - is an inherent part of politics, amidst a struggle to politicise the oikos and depoliticise the polis within a zone of indistinction.

To understand this in application, we must also briefly consider Agamben's broader work on sovereignty. For Agamben, political power is biopolitical, seeking the regulation of life through the targeted governance techniques of the state. Essential to this is the establishment of a state of emergency and the creation of hominus sacri, the individual who can be killed but not sacrificed, simultaneously bound by the law yet receiving no protection. ${ }^{8}$ Put another way, political meaning can be stripped from life as it is rendered natural, zoe, rather than of the Aristotelian good life, bios.

In this view, 
the realm of bare life - which is originally situated at the margins of the political order gradually begins to coincide with the political realm, and exclusion and inclusion, outside and inside, bios and zoe, right and fact, enter into a zone of irreducible indistinction. At once excluding bare life from and capturing it within the political order, the state of exception actually constituted, in its very separateness, the hidden foundation on which the entire political system rested. ${ }^{9}$

Parallels with the distinction between oikos and polis are apparent, as the exclusive inclusion captures all within the governmental machinery of the state. Here, we see that political life is shaped by the inimitable struggle between oikos and polis, along with efforts to regulate life that transcend the political realm to be all encompassing. It is here that we see the emergence of stasis as an effort to regulate that which facilitates the emergence of politicisation and the move from oikos to polis, a movement that transgresses pure political issues.

Although not without problems, particularly concerning the application of the ideas of stasis, bare life and state of exception to the Middle East, these are not insurmountable, as Mabon has argued elsewhere. ${ }^{10}$ Indeed, the Middle East provides fertile ground for consideration of the implications of such discussions. With this in mind, let us turn to a consideration of Iraqi politics, wherein we can see the creation of hominus sacri through the simultaneous exclusion and inclusion of life within political and legal spheres. Such exclusive inclusion has historically taken place along sectarian lines as a mechanism of control, where efforts to regulate life have separated oikos from polis. With this in mind, and beginning from the assumption that the citizens of Iraq constitute an oikos - a necessary but logical assumption - we proceed to explore the transgression of the zone of indistinction into stasis.

\section{Narratives of Exclusion}

Oh, if we can pull this thing off! Rope together the young hot-heads and the Shi'ah obscurantists, and the enthusiasts [...] if we can make them work together and find their own salvation for themselves, what a fine thing it will be. I see visions and dream dreams. ${ }^{11}$,

The story of the contemporary Iraqi state is one of exclusion and persecution. Amidst struggles to create a national project and to regulate life, the creation of narratives of belonging - coeval to which were narratives of exclusion - played a central role. The -The severity of the problem facing Faisal, the first King of Iraq ${ }_{2}$ was not lost on him, as presented-anecdotally by T.E. Lawrence:

There is still - and I say this with a heart full of sorrow - no Iraqi people but unimaginable masses of human beings, devoid of any patriotic idea, imbued with religious traditions and absurdities, connected by no common tie, giving ear to evil, prone to anarchy, and perpetually ready to rise against any government whatsoever. ${ }^{12}$

The existence of myriad peoples within spatial borders posed serious challenges for those wishing to establish biolpolitical control. Some such as Adham Saouli ${ }^{13}$ suggest that divisions that began to characterise the Iraqi state were a consequence of the failure of the statebuilding project. In contrast, a different position argues that the manifestation of sectarian

Commented [JE1]: These were Faisal's words, no? So they were presented to T.E. Lawrence, not by him, right? 
violence is a consequence of socio-economic factors, contingent upon time and space which requires the development of an 'other' to oppose the nationalist project. If one considers the writings of Gertrude Bell, the intrepid British explorer and political advisor, it is easy to see how perceptions of the other and ideas of external interference that are imbued in othering shaped decisions at the time:

The proximity of Persia and the existence in Mesopotamia of Karbala and Najaf, two of the most holy shrines of the Shiah sect, to which the Persians belong, with the resulting influx of Persian pilgrims, have brought the country much under Persian influences. Nomad Arabia belongs wholly to the Sunni half of Islam, yet the tribes settled in Mesopotamia have embraced, almost without exception, the Shiah faith. ${ }^{14}$

From the establishment of the state until 2003, sectarian difference was propagated as a mechanism of survival, seeking to curtail the power of the Shi'a clerics and ensuring the survival of successive regimes. ${ }^{15}$ Across the state building process, political rule has been facilitated and characterised by sectarian difference which has become a prominent feature of political, economic and social life. With the establishment of the British Mandate in 1921, political life across Iraq was defined by efforts to regulate life and to maintain power. A year previously, a nationalist revolt took place across the country, resulting in the deaths of over 300 British and Indian soldiers and a further 1200 wounded, costing the British Exchequer around $£ 40,000,000$. As a consequence of their acquiescence, the British rewarded powerful Sunnis in Baghdad with prominent political positions, in doing so institutionalising the sectarian schism that would define Iraqi politics until 2003.

Yet sectarianism need not have necessarily become such a feature of political life. In the years prior to the formation of the state, a number of nationalist organisations were established across southern Iraq that drew upon religious figures and political activists from both Sunni and Shi'a constituencies, yet in the years that followed, organisations would take on an explicitly sectarian dimension. Writing at the time, Gertrude Bell stressed the unity of such groups, where "the nationalists had picked up their tempo in continual meetings at the mosques. Extremists are calling for independence and refuse moderation and these have dominated the mob in the name of Islamic unity and the rights of the Arabs." ${ }^{16}$

Following the British embrace of the Sunni bourgeoisie, sectarian difference became a prominent feature of the nascent Iraqi state. As Adeed Dawisha outlines

no Shi'ite was accepted in the military college or in the bureaucracy, except on very rare occasions. There were all kinds of hurdles preventing Shi'ites from even entering high schools. The State did not think of the Shi'ite community as part of it, and the Shi'ites did not consider themselves to be part of the state. ${ }^{17}$

Such processes continued as the state developed.

With the establishment of the Ba'ath rule in 1958, Sunni positions of power were strengthened, particularly after the emergence of Saddam Hussein, whose brutal rule was held together by a strong nationalist presence: staunchly Sunni, with his Tikriti tribal group a central part of his political vision. To ensure his survival, as Charles Tripp notes, political 
processes were designed to retain power and exacerbating difference as a mechanism of control. $^{18}$

In an effort to retain power, Saddam mobilized networks of patronage to bring peripheral actors into the political fray, transforming local interests by allying them alongside burgeoning national interests. ${ }^{19}$ The transformation of Iraq in the following decades required migration from rural to urban environments, changing the demographics of city life, emerging from the abolition of the 1933 Law Governing the Rights and Duties of Cultivators. ${ }^{20}$ Although explicitly Sunni, the Ba'ath project positioned itself against "religious sectarianism (al-ta'ifiyya), racism, and tribalism (al-qabaliyya)," ${ }^{21}$ yet in reality, life across Iraq was dramatically different. Key ministries were dominated by Sunnis, who made up 70\% of the army after the 1958 coup, whilst the rest was comprised of $20 \%$ Shi'a and $10 \%$ Kurds and other minorities. ${ }^{22}$

Whilst opposition groups emerged in opposition to the Ba'ath regime, they faced serious challenges. ${ }^{23}$ Al Da'awa al Islamiyah and Al Mujahidin drew support from a wide range of Shi'a groups, the former from Shi'a clerics and those marginalized from political life, ${ }^{24}$ whilst the latter from religious graduates from Iraqi schools. Both drew inspiration from the teaching of Muhammad Baqir al-Al-Sadr, who was later executed by Saddam in an attempt to crush the burgeoning Shi'a movements. The execution of aAl-_Sadr fed into Shi'a myths and narratives of resistance, guilt and martyrdom found in the Karbala narrative, ${ }^{25}$ whilst also positioning the al-AlSadr as one of the most influential political families in Iraq. An additional consequence of this was to help the Sadr family challenge the "-quietist ayatollahs".'26 who had occupied a central position in Shi'a life across Iraq.

Although a prominent Shi'a figure, Muhammad Baqir al-Al-Sadr had rejected the sectarian divisions that had plagued Iraq since its formation. Writing from his cell in Baghdad, al-Al-Sadr called for unity amongst the Iraqi people:

Oh my dear people, I turn to you all, Sunnites and Shi'ites, Arabs and Kurds, in this crucial moment of crisis and jihad [...] since the crisis is that of the whole Iraqi people, the brave response and struggle must also become the reality of the whole Iraqi people. Thus I am with you, my Sunni brother and son, just as much as I am with you, my Shi'i brother and son [...] Oh my sons and brothers, the sons of Mosul and Basra, the sons of Baghdad, Karbala and Najaf [...] [unite in order to] build a free, glorious Iraq [...] where citizens of all nationalities and schools of thought would feel that they are brothers and would all contribute to the leadership of their country. ${ }^{27}$

Saddam's crackdowns on Shi'a groups forced many into Iran, where the newly formed Islamic Republic helped establish new groups such as the Supreme Council for the Islamic Revolution in an attempt to export the revolutionary goals of the Islamic Republic across the Muslim world. ${ }^{28}$

With the outbreak of the Iran-Iraq War, many shared Gertrude Bell's concerns from 60 years previously, that the long-marginalized Shi'a groups across Iraq would support their coreligious kin in Iran. Playing on this narrative, one Iraqi newspaper sought to blame Iranian actors: 
The ruling clique in Iran persists in using the face of religion to foment sedition and division among the ranks of the Arab nation despite the difficult circumstances through which the Arab nation is passing. The invocation of religion is only a mask to cover Persian racism and a buried resentment of the Arabs. ${ }^{29}$

After the war, unrest continued across the southern parts of Iraq, drawing support from a range of upon Shi'a groups, and disaffected soldiers and deserters. In response, Saddam responded with force, committing atrocities 'on a predictably massive scale' resulting in huge numbers of internally displaced people and refugees, whilst feeding deep-seated grievances amongst Shi'a communities. ${ }^{30}$

When US led forces toppled the Ba'athist regime in March 2003, latent structural grievances that had lain dormant since the establishment of the Iraqi state manifested in violence across the state as Iraq rapidly descended into the stasis of civil war. ${ }^{31}$ In the years that followed, Shi'a groups became increasingly influential as nationalist identity was superseded in the political arena by sectarian allegiance. In areas facing serious socio-economic challenges, populist groups emerged, coalescing around figures who were able to draw legitimacy from family lineages, such as Muqtada al-Al-Sadr, who espoused vehemently sectarian narratives that undermined (often token) attempts to retain nationalist unity by regimes in Baghdad. ${ }^{32}$

Shi'a clerics across the south of the state took on an important guidance role. Although typically viewed as "--quietist"'-, clerics such as Grand Ayatollah Ali al-Sistani became incredibly influential, seeking to transcend sectarian difference. Yet fatwas calling for jihad against Da'ish would later be viewed as inciting violence against Sunnis. In spite of this perception, Sistani sought to circumvent such tensions, urging Shi'a not to "call Sunnis our brothers, call them ourselves". At this point, the melange of identities operating across Iraq restricted the space for opposition identities to act. The various political, social and religious sub-state groups across Iraq - defined along tribal, ethnic or sectarian lines, where class cut across allwas described by Fanar Haddad as "-the mutually antagonistic other of national identity"-..

Simultaneously, al-Al-Qa'ida in Iraq had become an important actor in the sectarian conflict. Prior to the 2003 invasion, a Jordan Salafi named Abu Musab al-Zarqawi had entered Iraq to fight along Ansar al-Islam in Kurdistan but when the war escalated in 2004 he and his organization declared allegiance to Osama bin Laden. Later, going against the wishes of Bin Laden, Zarqawi declared full out war against the Shi'a population with the intention of exacerbating the sectarian conflict in the hope that the Iraqi state would crumble, exacerbating sectarian divisions. ${ }^{34}$

Despite al-Al-Qa'ida in Iraq's desire to dominate the insurgent groups, there was a reversal in public support that ended in the Anbar Awakening where a coalition of Sunni tribes was brought together and funded by the US military in an attempt to empower Sunnis in the fight against al- $A \backslash$ Qa'ida. At first, the Anbar Awakening empowered Sunnis, however the aftermath quickly soured when the government in Baghdad failed to bring the leaders of the movement into the state infrastructures and providing the region with sufficient resources and security, fueling Sunni grievances towards the Shi'a led government. ${ }^{35}$ 
In such an environment, political space for Sunnis was restricted as they were caught between the government of Nouri al-Al-Maliki, Shi'a militias, al-Al-Qa'ida and US-led coalition forces. An International Crisis Group report documents the challenges facing young Sunnis, who "share the concerns of all young Iraqis, as they see the government operating in slow motion only. But, beyond that, they also feel that they do not enjoy the same opportunities as others. They have yet to feel accepted by society and resent being suspected of affiliation with alQaeda." 36

Such perceptions were shaped by broader Iraqi political discourse and policies. As Mabon and Royle note, the Maliki and Abadi governments were characterised by marginalisation, discrimination and exclusion, albeit in different forms. The Maliki regime deployed a "-top down $n_{-}^{\prime \prime}$ approach to cultivating sectarian difference whilst the Abadi government sought to remove such sectarian tensions, although the repercussions of Maliki's policies continue to be felt through the cultivation of sectarian difference within institutions and across socioeconomic communities. As time went on, the struggle to find an outlet for grievances or political leadership became an increasingly important issue =- even after the destruction of the caliphate - feeding into the growth of deep structural grievances.

\section{Demographic changes, Oikos, Sect and the Geopolitical Allegiance}

Conflicting political agendas between state and family created divisions across society that led to entrenched divisions across all aspects of the state. Amidst such existential concerns, the inclusion of one group in politics has resulted in the exclusion of another group. These structures have changed over time, firstly benefiting the Arab Sunnis during Saddam's regime while the Shi'a and Kurds faced violent discrimination and marginalisation whilst after the 2003 invasion the tables were turned and the Arab Sunnis became marginalised.

The tension that built up in Iraq between the different groups escalated over time, eventually leading to stasis. During Saddam's rule, conflicting ideas and political dissent were suppressed or pushed to the periphery, perhaps best seen in the Shi'a insurgency in rural areas across southern Iraq, but has since escalated and now includes the indistinction of the rural and the city, the friend and the enemy; it is all encompassing.

During the Ba'athist rule the political arena was shaped by interactions between the centre and the periphery. Although the rural population has dwindled over the last century the Iraqi state was never strong enough to maintain control over the peripheral regions. ${ }^{37}$ Consequently, Saddam utilised his networks of patronage to maintain order in the peripheries though a carrot-and-stick system where supportive tribes was rewarded for their loyalty and disloyalty was punished by death, violence and torture. ${ }^{38}$ This meant that Saddam could retain control over exterior Iraq with minimal intervention. However, it also meant that the collective identity creation of Iraq was placed on hold and the tribal and religious values were given space to continue in the peripheries.

During Saddam's rule, tribes provided security and justice within their own vicinities and collected tax on behalf of the state, even in Kurdish and predominantly Shia Muslim areas 
after the First Gulf War. ${ }^{39}$ However, autonomy-state authority remained limited in the peripheries, resulting in competing forms of governance. For example, the population in the south, including Shi'a and Arab Sunni, were only allowed to settle civil cases while in Anbar they were permitted to settle murder cases, revealing the complexity and difference of governance and legal structures. ${ }^{40}$

Saddam also harnessed different identities to keep a hold over the population including tribal values, Arab nationalism, and Ba'athist ideology. During the Iran-Iraq war when Iran pledged support to Shi'a insurgents in Iraq, Saddam used the banner of Arabism to urge the Arab Shi'a to remain loyal to their ethnic kin, even if that meant even further alienate the Kurds. ${ }^{41}$ Other individuals who were not regarded Arab but rather "-Iranian nationals"-' or Persians in Iraq became further marginalised and racism became commonplace. The dismay increased further when 35,000 people allegedly of Iranian descent were expelled to Iran and Iraq's most influential Shi'a cleric -_ Muhammad Baqir al-AlSadr ${ }_{-}$was executed in $1980 .{ }^{42}$ In spite of alAl-Sadr's pleas to the contrary, sectarian divisions increased during this period and geopolitical actors in Tehran and Riyadh sought to support their kin in Iraq thus further fragmenting the political order.

The political climate changed after First Gulf War when Saddam changed tactics in order to maintain power. After the war, Saddam took the decision to dry out the Mesopotamian marshes in southern Iraq in order to punish the Marsh Arab Tribes that had risen against him during the war, whilst also depriving the Shi'a opposition of its base of operations. ${ }^{43}$ This large project required canals to re-divert the river, internally displacing between 100-200,000 people and creating more that 100000 international refugees, most of whom crossed the border into Iran. ${ }^{44}$ This case in particular reveals the tension between the oikos and the polis in the periphery, as a consequence of Saddam's retribution against tribal and sectarian division, displacing thousands in the process.

In urban spaces, governmental machinery helped regulate the Iraqi state, although it was not without challenges. During this period, urban spaces expanded dramatically, with 19 million living under Baghdad's control ${ }^{45}$ and over $55 \%$ living in impoverished conditions. ${ }^{46}$ Furthermore, with the Ba'ath party being the largest employer having ownership of the public sector, the Arab Sunni was given preferential treatment whilst Shi'a and Kurds were marginalised from public employment. ${ }^{47}$ The impact of reciprocal exclusion and marginalization was largely overlooked in the aftermath of 2003, when the political arena changed. Such events reveal tensions in both the oikos and polis, particularly when the politics of the sovereign state is coterminous with tribal and sectarian politics.

The collapse of Saddam's regime allowed previously marginalized actors to lay claim to power. Consequently, the Iraqi Governing Council openly declared sect and ethnicity to be primary principles for political organization. Shi'a and Kurdish leaders believed that that the new Iraq should reflect the demographic organization of the population, which would increase their power across regions and the state itself. However, Sunni Arabs argued that this was an American strategy playing into a policy of divide and rule that would ultimately result in sectarian conflicts. ${ }^{48}$ 
The changing political arena divided political opinions and many Sunni Arabs argued that the de-Bba'athification process - = later described as one of the biggest mistakes made by


power. This was exacerbated by the fact that US brought Shi'a and Kurdish groups into negotiations, while Sunni Arab groups were looked at with suspicion and largely placed on the peripheral rejected from the political centre. ${ }^{49}$ In the aftermath of the 2003 invasion, a new form of stasis emerged.

In the vacuum that emerged, previously marginalized communities sought to exert revenge on the state that had previously regulated all aspects of their lives. In this context, Sunni Arabs became economically and politically marginalised, leading to conditions in which individuals were forced to turn to a range groups such as Da'ish for survival without necessarily sharing their ideological vision. ${ }^{50}$ Adding to this, many of the $35_{-}-000$ prisoners imprisoned by Saddam resorted to crime after their release, resulting in gangs looting army storage facilities which were later sold on the black market. ${ }^{51}$ In the meantime, thousands of Iraqis, many of them civilians, were imprisoned and subjected to inhumane treatment in the Abu Ghraib and other prisons, fuelling Sunni grievances. ${ }^{52}$

At this point, sectarian violence became an almost defining feature of Iraqi politics. Amidst pressure from formal government structures and informal Shi'a militias, Sunni groups faced seemingly existential challenges for survival. As Mabon and Royle document in The Origins of $I S I S$, the impact on human agency at this time was particularly devastating, especially for Sunnis who were trapped between the Shi'a led government, Shi'a militias, a violent al-At Qa'ida franchise, and coalition forces. ${ }^{53}$ Moreover, at this point, Shi'a militias were able to execute violence on Sunnis across Iraq, seemingly with impunity, leaving Sunnis bound by state law yet abandoned by it in a living example of Agamben's homo sacer.

Consequently, during this period the tribe became even more important for the Sunni Arab tribe members, not just in the political arena but also for survival. During the deB ba'athification around $300_{-}-000$ people previously employed in by the Ba'athist state struggled to find work and protection for their families, ${ }^{54}$ including doctors and teachers. ${ }^{55}$ With the tables turned employment in the public sector remained high at approximately $30 \%,{ }^{56}$ with Shi'a holding many of the positions using the ministers to serve the tribe and the tribal leaders rather than the state of Iraq. As a result, Sunni Arabs was caught between the Shi'a government in Baghdad, Shi'a militias and $\underline{a}-\mathrm{Al}-\mathrm{Q} a{ }^{\prime}$ 'ieda. ${ }^{57}$

The destabilisation of Baghdad led the US military build sections concrete partitioning walls to divide the communities and imposed check points, buffer zones, collective punishments, impersonating of suspect relatives, mass incarcerations without trial and bulldozing landscapes believed to be harbouring the enemy. ${ }^{58}$ In Baghdad, the Shi'a cleric Muqtada alAl-Sadr revived Mahdi Army, an explicitly Shi'a militia which regulated life across the poorer parts of the city, imbuing such areas with an almost militant sense of Shi's community, helped by his family's clerical heritage.

Simultaneously, al-AlQa'ieda adopted strategies to target Shi'a communities, symbols, holy places and leaders. Their aim was to exacerbate the sectarian conflict with Shi'ites that would lead to the collapse of the state amidst the violent rejection of the Shi' ${ }_{-=}^{-}$both Iraqi and 
Iranian =- albeit acting in direct contravention of the messages of both Osama bin Laden and Ayman al-AlZawahiri. ${ }^{59}$ Their tactics included mass casualties suicide bombings, kidnappings and beheading of hostages. Increasingly, the Shi'a population was killed or displaced form Sunni majority or mixed population areas. ${ }^{60}$ By the end of the 2000 s tens of thousands of Iraqis had been killed during the civil war. Al-Al-Qa'ieda and other Sunni insurgent groups controlled the western and northern parts of Iraq, while Mahdi Army controlled large areas of Baghdad and had strong political associations to the south.

Within the context of the disintegration of the Iraqi state, the ability of Baghdad to exert its control over Iraqi territory greatly diminished, creating opportunities for new actors to emerge. At the heart of the growing sectarian divisions of the Iraqi state lies the infiltration of the state by external geopolitical agendas. Since the 1979 revolution in Iran, Saudi Arabia and Iran have been caught in a rivalry that is increasingly framed along sectarian lines but is predominantly geopolitical in nature, resulting in the emergence of spaces of competition across the Middle East. In Iraq, the two actors have been keen to support their kin and the fragmentation of Iraq has meant that Riyadh and Tehran has been able to exacerbate the conflicts between the communities. ${ }^{61}$ Iran in particular wanted to influence the Shi'a in the south to gain access to the holy cities of Karbala and Najaf.

One example of this is Iranian financial support to Shi'a militias across the state, with whom Iran has strong ties having especially the Badr Brigades which has been regarded as an Iranian puppet and viewed as an extension of the Iranian Revolutionary Guards Corps. ${ }^{62}$ The Badr Brigades provided security in Shi'a and mixed areas in Baghdad, including patrolling and creating checkpoints. ${ }^{63}$ Further alienating the Sunni population in the city. The Arab Sunni communities, which are heterogeneous, were now viewed as either Ba'athist or terrorists and they were readily targeted by Badr Brigade and other militias. The reinforcement of the sectarian divisions by geopolitical actors has been devastating in the fragmentation of the Iraqi state, especially in the marginalisation and exclusion of the Sunni Arab communities.

Saudi policy at this time was driven by long-standing concerns at expansionist Iranian activity on its northern border. US diplomatic cables released by Wikileaks details document the fears of many in the Kingdom. One cable from 2009 denotes the lack of confidence in Iraqi political leaders:

The King said he had "no confidence whatsoever in (Iraqi PM) Maliki, and the Ambassador (Fraker) is well aware of my views." [...] For this reason, the King said, Maliki had no credibility. "I don't trust this man," the King stated, He's an Iranian agent." [...] Maliki has "opened the door for Iranian influence in Iraq" since taking power, the King said. ${ }^{64}$

A year earlier, the Saudi leadership had urged the US to undertake a military strike against Iran to curtail both its nuclear programme and its perceived nefarious activities across the region:

the King's frequent exhortations to the US to attack Iran and so put an end to its nuclear weapons program. "He told you to cut off the head of the snake," he recalled to the Charge', adding that working with the US to roll back Iranian influence in Iraq is a strategic priority for the King and his government. ${ }^{65}$ 
These fears were also echoed by King Hamad of Bahrain who stated that "as long as Khamenei has the title of Commander-in-Chief, Bahrain must worry about the loyalty of Shia who maintain ties and allegiance to Iran". ${ }^{66}$ Such comments were underpinned by what King Abdullah of Jordan referred to as a "'Shi'a Crescent"'-, which came to be the dominant lens through which to view Iranian activity and aspirations across the region. It is in this climate that the broader categories of Sunni and Shi'a become conflated with the geopolitical aspirations of political actors across the Middle East. ${ }^{67}$

In later years, Saudi policy towards Iraq would dramatically shift. The Saudi embassy in Baghdad was re-opened in 2016 after a 25-year closure. Riyadh also sought to counter Iranian influence by speaking to Shi'a militias led by Muqtada al-Al-Sadr, who visited the Kingdom in 2017, in an effort to capitalise on a rising Iraqi nationalism that seemed at odds with the Khomeini's vision of veleyat-e faqi. Yet in spite of rumours of a burgeoning rapprochement, al-Al-Sadr continued to side with Iran after the 2018 elections.

Whilst the importance of the rivalry between Saudi Arabia and Iran should not be ignored, it should not be overstated. Three different positions on the rivalry have emerged in recent years. The first suggests that this is a political struggle whilst the second argues that it is primarily a consequence of sectarian difference. The third, which we subscribe to, is that politics and religion interact with one another in different forms, shaped by the interaction of context specific contingent factors with broader regional trends. It is this view that helps us to understand the construction of Iraqi politics and ultimately, stasis. how

\section{Da'ish, Stasis and bare life in Iraq}

The emergence of Da'ish is a consequence of the cultivation of bare life across Iraq. Put another way in explicitly Agambenian terms, the politicisation of the oikos within the polis and collapse of both blood kinship and political kinship amidst the depoliticisation of the polis facilitated a zone of indistinction from which violence emerges. Through exclusion, marginalization and persecution, Sunnis across Iraq felt a sense of abandonment, lacking political and existential protection as a consequence of both Iraqi and regional machinations. As Agamben suggests, stasis is inherent within the fabric of the state, emerging amidst efforts to (de)politicize events and people in the struggle to regulate life. This struggle has characterised Iraq from the establishment of the British mandate to the Prime Ministership of Haider al-AłAbadi, who continues to challenge the inherent sectarianism that continues to shape structural factors within Iraqi politics.

Addressing such structural factors is an essential part of preventing the emergence of future instances of stasis and future incarnations of violent Sunni extremism. In spite of this aspiration, Agamben suggests that it is an inevitable aspect of political organisation. Such a negative view of politics and human agency is a regular feature of Agamben's work, yet we should not be too quick to ignore the power of agency. As the likes of Patricia Owens have suggested, agency can be expressed in myriad forms and contexts, even within bare life. 
Although deeply pessimistic, Agamben suggests that stasis can be avoided through recourse to the oikos and the development of a truce between competing visions of the political. It is only through truly understanding the relationship between the politicised and the depoliticised, the oikos and polis that we are able to work towards preventing the emergence of stasis.

\footnotetext{
${ }^{1}$ Nicole Loraux “La guerre dans la famille," Clio, 5, no.21-62 (1997): 38.

2 Giorgio Agamben, Homo Sacer: Sovereign power and Bare life (California: Stanford University Press, 1998)

${ }^{3}$ Agamben begins his essay lamenting the lacuna of intellectual focus upon the conditions of civil war that give scope for external intervention in political life.

${ }^{4}$ Agamben, Stasis (Edinburgh: Edinburgh University Press, 2015), 5.

${ }^{5}$ Agamben, Stasis, 12.

${ }^{6}$ Agamben, Stasis, 7.

${ }^{7}$ Agamben, Stasis, 11.

${ }^{8}$ Giorgio Agamben, Homo Sacer.

${ }^{9}$ Ibid., 9.
}

${ }^{10}$ Simon Mabon, "Sovereignty, Bare Life and the Arab Uprisings," Third World Quarterly, 38, no. 8 (2017)

${ }^{11}$ Gertrude Bell, A Woman in Arabia: The Writings of the Queen of the Desert (New York:

Penguin Books, 2015 [ed. Georgina Howell]), 195.

12 T.E. Lawrence, "Faisal's Table Talk," report to Colonel Wilson, Jan. 8, 1917, FO 686/6, 121. Faisal's remarks are also quoted in: Hanna Batatu, The Old Social Classes and the Revolutionary Movements in Iraq (Princeton, N.J.: Princeton University Press, 1978), 25-6.

${ }^{13}$ Adham Saouli, The Arab State: Dilemmas of Late Formation (London: Routledge, 2012).

${ }^{14}$ Bell, A Woman in Arabia, 169.

${ }^{15}$ Mabon and Royle, Origins of ISIS (London: I.B.Tauris \& Co. Ltd, 2017).

${ }^{16}$ Gertrude Bell, in Amal Vinogradov, "The 1920 revolt in Iraq reconsidered," International Journal of Middle East Studies 3, no. 2 (1972): 135.

${ }^{17}$ Adeed Dawisha, Iraq: A Political History from Independence to Occupation (New Jersey: Princeton University Press, 2009), 72.

${ }^{18}$ Charles R. H. Tripp, A History of Iraq (Cambridge: Cambridge University Press, 2007), 75.

${ }^{19}$ Tripp, A History of Iraq, 48-50.

${ }^{20}$ Amatzia Baram, "Neo-tribalism in Iraq: Saddam Hussein's Tribal Policies 1991-96," International Journal of Middle East Studies 29, no. 1 (1997): 3.

${ }^{21} \mathrm{Ibid}$.

${ }^{22}$ Ahmed S. Hashim, "Military power and state formation in modern Iraq," Middle East Policy 10, no. 4 (2003): 29.

${ }^{23}$ Hanna Batatu, "Iraq's Underground Shi'I Movements" (MER102, 1981), accessed on 13 Desember, 2015, http://www.merip.org/mer/mer102/iraqs-underground-shii-movements. ${ }^{24}$ Soren Schmidt, "The role of religion in politics. The case of Shia-Islamism in Iraq," Nordic Journal of Religion and Society, 22, no. 2 (2009): 129.

${ }^{25}$ Simon Mabon, "The Circle of Bare Life: Hizballah, Muqawamah and Rejecting 'Being Thus'," Politics, Religion \& Ideology, 18, no. 1 (2017).

${ }^{26}$ Soren Schmidt, "The role of religion in politics," 137. 
${ }^{27}$ Amatzia Baram, "The radical Shi'ite opposition movements in Iraq", in Emmanuel Sivan and Menachem Friedman (eds), Religious Radicalism and Politics in the Middle East, (Albany: State University of New York Press, 1990), 108-9.

${ }^{28}$ Other notable groups established at this time with Iranian assistance include Hizballah and the International Front for the Liberation of Bahrain.

${ }^{29}$ Al Thawra (Baghdad), 18 September 1980, quoted in Dawisha, Iraq: A Political History, 554.

${ }^{30}$ Human Rights Watch, Endless Torment: The 1991 Uprising in Iraq and Its Aftermath (1992), available from www.hrw.org/reports/1992/Iraq926.htm.

${ }^{31}$ Mabon and Royle, Origins of ISIS.

32 Ibid., p. i.

${ }^{33}$ Fanar Haddad, "Sectarian relations in Arab Iraq: contextualising the civil war of 20062007," British Journal of Middle Eastern Studies, 40, no.2 (2013): 115-38, 2.

${ }^{34}$ Safa R. al-Sheikh and Emma Sky, "Iraq since 2003: Perspectives on a divided society", Survival 53, no.4 (2011): 123.

${ }^{35}$ Austin Long, "The Anbar Awakening," Survval: Global Politics and Strategy, 50, no.2 (2008): 85.

${ }^{36}$ International Crisis Group interview with a prominent Iraqi human rights activist.

${ }^{37}$ Mabon and Royle, Origins of ISIS, 82.

${ }^{38}$ Amatzia Baram, "The Iraqi armed forces and security apparatus," Conflict, Security and Development, 1, no. 2 (2001): 114.

${ }^{39}$ Mabon and Royle, Origins of ISIS, 83.

${ }^{40}$ Katherine Blue Carroll, "Tribal Law and reconciliation in the New Iraq," Middle East Journal, 65, no. 1 (2011): 18.

${ }^{41}$ Arab Human Development Report, Towards Freedom in the Arab World (2004), 7, available from http://www.arab-hdr.org/reports/2004/english/ahdr2004e.pdf?download. ${ }^{42}$ Adeed Dawisha, "“Identity" and Political Survival in Saddam's Iraq," 557.

43"Marsh flooding bring new life to Iraq's 'garden of eden'," BBC, accessed 22 June, 2018, https://www.bbc.co.uk/news/magazine-22706024.

${ }^{44}$ Danish Institute for international studies, What happended to the Iraqi Marsh Arabs and their land? The myth about the garden of eden and the noble savage (2015), 4, accessed 22 June, 2018, https://www.files.ethz.ch/isn/18548/Iraqi Marsh Arabs.pdf.

${ }^{45}$ Adeed Dawisha, "“Identity" and Political Survival in Saddam's Iraq," Middle East Journal, 53, no. 4 (1999): 556.

${ }^{46}$ Mostafa K. Tolba and Najib W. Saab, Arab environment future challenges (2008), 40, available from http://www.afedonline.org/afedreport/full\%20english\%20report.pdf.

${ }^{47}$ Tareq Y Ismael and Jacqueline S Ismael, "Wither Iraq? Beyond Saddam, Sanctions and Occupation", Third World Quarterly, 26, no. 4-5 (2005): 612.

${ }^{48}$ Safa R. al-Sheikh and Emma Sky, "Iraq since 2003," 120.

${ }^{49}$ Mabon and Royle, Origins of ISIS, 84.

${ }^{50}$ Simon Mabon, "Nationalist Jāhiliyyah and the Flag of the Two Crusaders, or: ISIS, Sovereignty and the "Owl of Minerva"," Studies in Conflict \& Terrorism, 40, no. 11 (2017): 969.

${ }^{51}$ Safa R. al-Sheikh and Emma Sky, "Iraq since 2003," 120.

${ }^{52}$ Arab Human Development Report, Towards Freedom in the Arab World, 7.

${ }^{53}$ Mabon and Royle, Op. Cit. See, in particular, chapter 5: The Human Cost. The chapter documents the devastating impact that consecutive governments had on the people of Iraq, 
amidst repeated marginalization and exclusion, along with creating the conditions that give rise to informal groups acting conducting violence with impunity.

${ }^{54}$ Simon Mabon, "Nationalist Jāhiliyyah and the Flag of the Two Crusaders," 969.

${ }^{55}$ Safa R. al-Sheikh and Emma Sky, "Iraq since 2003," 121.

${ }^{56}$ Arab Human Development Report, Youth and the prospects for human development in a changing reality (2016) p.29

${ }^{57}$ Simon Mabon, "Nationalist Jāhiliyyah and the Flag of the Two Crusaders," 969.

58 Stephen Graham, Cities under siege: The new military urbanism (London: Verso, 2010), 242.

59 ibid.

60 ibid.

${ }^{61}$ Simon Mabon, "Nationalist Jāhiliyyah and the Flag of the Two Crusaders," 970.

${ }^{62}$ Safa R. al-Sheikh and Emma Sky, "Iraq since 2003," 130.

${ }^{63}$ Simon Mabon, Saudi Arabia and Iran: Power and Rivalry in the Middle East (London: I.B.Tauris \& Co. Ltd, 2013), 69.

64 “09RIYADH447_aCOUNTERTERRORISM ADVISER BRENNAN'S MEETING WITH SAUDI KING ABDULLAH," Wikileaks, accessed 22 March, 2014,

https://wikileaks.org/plusd/cables/09RIYADH447 a.html.

65 "08RIYADH649_a SAUDI KING ABDULLAH AND SENIOR PRINCES ON SAUDI POLICY TOWARDS IRAQ," Wikileaks, accessed 20 April, 2008,

https://wikileaks.org/plusd/cables/08RIYADH649 a.html.

66 “O6MANAMA409_a LUNCHEON WITH KING HAMAD," Wikileaks, accessed 15 March, 2006, https://wikileaks.org/plusd/cables/06MANAMA409 a.html.

${ }^{67}$ Simon Mabon, "Muting the Trumpets of Sabotage: Saudi Arabia, the US and the quest to securitize Iran," British Journal of Middle Eastern Studies, (2017). 